\title{
Implementasi Peta Pikiran (Mind Mapping) dalam menguasai Teori Kejuruan, untuk Meningkatkan Hasil Belajar Siswa Pada Mata Pelajaran Produktif siswa kelas X Tata Kecantikan Rambut
}

\author{
Made Sumiati
}

SMK Negeri 3 Bogor, Indonesia

Email: madesumiati@gmail.com

\begin{tabular}{l}
\hline Tersedia Online di \\
\hline http://www.jurnal.unublitar.ac.id/ \\
index.php/briliant \\
\hline
\end{tabular}

\section{Sejarah Artikel}

Diterima pada 7 Agustus 2020

Disetujui pada 27 Agustus 2020

Dipublikasikan pada 31 Agustus 2020 Hal. 551-561

\begin{tabular}{l}
\hline Kata Kunci: \\
\hline Mind Mapping; teori kejuruan; \\
tata kecantikan rambut; SMK \\
\hline DOI: \\
\hline http://dx.doi.org/10.28926/briliant \\
.v3i4.534
\end{tabular}

\begin{abstract}
Abstrak: Siswa Tata Kecantikan Rambut kelas X tahun ajaran 2010/2011, rata-rata memiliki kemampuan akademik tergolong kurang. Mayoritas siswa kesulitan memahami teori, baik normatif, adaptif dan produktif. Pemahaman teori kejuruan sangat diperlukan tidak cukup mencapai KKM 75. Penelitian ini dilakukan guna menemukan model pembelajaran yang membantu siswa agar lebih mengerti, merangsang motivasi dan minat dalam belajar dengan pengelolaan kelas yang tepat yakni menerapkan teknik peta pikiran (Mind Mapping). Penelitian dilaksanakan dalam dua siklus, mulai bulan April hingga Juni 2011. Setiap siklus membahas Kompetensi Dasar yang berbeda dari dua Standar Kompetensi, yaitu melakukan pratata dengan Kompetensi Dasar; menjelaskan teknik pratata rambut sesuai dengan alat yang digunakan dan melakukan penataan (Hair Styling) dan menjelaskan Desain Penataan Rambut (Hair Styling). Siswa lebih mudah mengingat materi
\end{abstract} pelajaran dalam waktu yang singkat. Hasil penelitian menunjukkan bahwa antusias siswa dalam belajar dan prestasi belajar mereka meningkat, terlihat dari keaktifan di kelas pada siklus I sampai II, yaitu dari rerata 78 menjadi 88, serta hasil tes teori pada siklus II rerata 85,67 .

\section{PENDAHULUAN}

Kebanyakan siswa yang memilih SMK, memiliki kemampuan akademik lebih rendah dibandingkan dengan SMU (Fakhriyanur, 2016; Hajar \& Sari, 2018; Sobah Ch., Suherman, \& Wiharna, 2018). Seharusnya siswa yang memilih untuk mengikuti pendidikan kejuruan disamping harus memiliki minat yang tinggi, namun juga harus memiliki kemampuan akademik yang seimbang, sehingga mereka akan mampu menyelesaikan tugas praktik dengan maksimal. Kenyataan saat ini kondisi siswa SMK khususnya siswa Tata Kecantikan Rambut, kelas X, rata-rata memiliki kemapuan akademik tergolong kurang (hasil Tes akademik ratarata 100, data berdasarkan hasil tes potensial akademik sebelum memasuki SMK). Kondisi seperti ini diketahui rata-rata siswa mengalami kesulitan untuk memahami teori, baik pada pelajaran normatif, adaptif maupun teori produktif. Kebanyakan siswa hanya mampu nilai KKM saja, yaitu 75 padahal pamahaman teori kejuruan sangat diperlukan, apalagi saat ini ujian nasional khusus untuk teori kejuruan telah dilaksanakan. Hal ini sangat menghatirkan penulis.

Berbagai keluhan tentang siswa kepada wali kelas X Kecantikan Rambut, antara lain lemah dalam teori, terkesan malas dalam mengerjakan tugas yang 
diberikan guru. Dalam proses belajar mengajar sudah menggunakan model team teaching ternyata masih mengalami kesulitan mengajar. Dari hasil pengamatan kami selama hampir 9 bulan, ternyata kemampuan akademik secara merata untuk siswa kelas X TKR masih sangat kurang.

Pada dasarnya semua orang mempunyai potensi untuk belajar lebih efektif dan memperoleh hasil belajar yang optimal, apabila lingkungan belajar siswa mendukung, seperti; terciptanya pembelajaran yang menyenangkan dan bermakna bagi siswa (baik dalam bentuk prestasi yang tinggi, pengakuan, maupun rasa diterima oleh kelompok kelas), metoda mengajar yang variatif dan yang terpenting lagi adalah apa yang disampaikan oleh guru, siswa memahami dan pemahaman tersebut dapat bertahan lama dalam otak siswa (D'Antoni, Zipp, Olson, \& Cahill, 2010; L.E., 2018; Slavin, 2010).

Untuk menjawab masalah tersebut diperlukan penelitian model pembelajaran yang dapat membantu siswa lebih mengerti, merangsang motivasi dan minat siswa dalam belajar dengan pengelolaan kelas yang tepat. Banyak sekali metode pembelajaran aktif yang harus diterapkan oleh guru untuk menarik minat siswa untuk belajar khususnya membantu siswa yang mempunyai kemapuan akademik yang agak kurang, salah satunya adalah dengan menerapkan teknik peta pikiran atau mind mapping (Buran \& Filyukov, 2015; Crowe \& Sheppard, 2012; D'Antoni et al., 2010; Edwards \& Cooper, 2010).

Ketidakmampuan seseorang mengoptimalkan proses informasi di era globalisasi informasi menyebabkan banyak individu terhambat di dalam belajar ataupun bekerja (Sudarsana et al., 2019). Jika ditelaah lebih lanjut, sebenarnya terletak pada dua hal, yaitu pencatatan dan penyajian kembali, dimana saling berhubungan. Terkait dengan proses pencatatan, seringkali individu tanpa disadari membuat catatan yang tidak efektif (D'Antoni et al., 2010). Metode ceramah, hanya $40 \%$ siswa memperhatikan, dan dari $40 \%$ siswa tersebut hanya $70 \%$ materi dapat diserap dan bertahan pada sepuluh menit pertama dan kemudian setelah lewat sepuluh menit berikutnya, pemahaman siswa tersisa hanya $20 \%$ (Bany, Sunnati, \& Darman, 2014; Purnomo et al., 2013). Beberapa permasalahan pada metode ceramah, yaitu; (1) perhatian siswa berkurang setelah beberapa menit berlalu, (2) hal ini hanya bertahan lebih lama pada siswa yang mempunyai tipe audio, (3) banyak siswa yang tidak menyukai karena mereka bersifat pasif, cepat bosan . Metode ceramah kurang membuat siswa memahami pelajaran (Purnomo et al., 2013).

Alat bantu visual dalam pembelajaran dapat meningkatkan pemamahan siswa bertahan lebih lama danwaktu yang dibutuhkan menjadi lebih singkat jika mengajar mengunakan alat bantu visual dan audio (Deliany, Hidayat, \& Nurhayati, 2019; Febiharsa \& Djuniadi, 2018; Hastuti \& Budianti, 2014; Hayati \& Harianto, 2017; Sudarsana et al., 2019; Susanto, 2017; Ulfa, 2016). Namun demikian seperti kata semboyan yang telah disebutkan bahwa, dengan mendengarkan dan melihat sesuatu, belum cukup untuk mempelajari hal tersebut (Deliany et al., 2019; Susanto, 2017). Untuk memproses informasi secara efektif, memerlukan refleksi dari luar dan dari dalam. Jika kita mendiskusikan sesuatu dengan orang lain, otak kita akan dapat melakukan tugas lebih baik dari belajar. Sebagai contoh, hasil penelitian bahwa group dengan metode pengajaran diskusi (treatment group), mencapai angka dua level di atas pencapaian siswa yang tanpa metode diskusi, yang sebagai control group (Crowe \& Sheppard, 2012; Edwards \& Cooper, 2010; Hsiung, 2012; 
Johnson, Johnson, \& Smith, 2014). Bentuk pencatatan yang dapat mengakomodasi berbagai tujuan di atas adalah peta pikiran (mind map). Individu mampu mengantisipasi derasnya laju informasi dengan memiliki kemampuan mencatat yang memungkinkan terciptanya "hasil cetak mental" (mental computer printout), membantu mempelajari informasi yang diberikan, merefleksikan pemahaman personal atas informasi tersebut. Selain itu, memungkinkan terjadinya asosiasi yang lebih lengkap pada informasi yang ingin dipelajari, baik asosiasi antarsesama informasi yang ingin dipelajari atapun dengan informasi yang telah tersimpan sebelumnya di ingatan.

Peta pikiran mengefisienkan penggunaan waktu individu dalam mempelajari sesuatu informasi karena peta pikiran dapat menyajikan gambaran menyeluruh atas suatu hal sehingga individu dapat menguasai sesuatu hal, dalam waktu yang lebih singkat. Aplikasi peta pikiran memungkinkan terciptanya kreativitas individu untuk berpikir secara otomatis "memaksa" setiap individu untuk berpikir melampaui batasannya. Jika individu menggunakannya, maka ia membuatnya lebih muda (Buran \& Filyukov, 2015; Crowe \& Sheppard, 2012; Edwards \& Cooper, 2010).

Mind map adalah alat pikir organisasional yang baik, karena dapat menempatkan informasi ke dalam otak dan mengambil informasi ke luar dari otak (Buran \& Filyukov, 2015). Mind map merupakan peta rute yang lengkap bagi ingatan, memungkinkan kita menyusun fakta dan pikiran sedemikian rupa sehingga cara kerja alami otak dilibatkan sejak awal (Edwards \& Cooper, 2010). Ini berarti mengingat informasi akan lebih mudah dan lebih bisa diandalkan daripada menggunakan teknik pencatatan tradisional. Mind map menggunakan warna, dan memiliki struktur alami yang memancar dari pusat, menggunakan garis lengkung, simbol, kata, dan gambar yang sesuai dengan satu rangkaian aturan yang sederhana, mendasar, alami, dan sesuai dengan cara kerja otak.

Langkah dalam membuat mind map yaitu:

a. Mulailah dari bagian tengah kertas kosong yang sisi panjangnya diletakan mendatar, dengan tujuan memberi kebebasan kepada otak untuk menyebar ke segala arah dan untuk mengungkapkan dirinya agar lebih bebas dan alami.

b. Gunakan gambar atau foto untuk ide sentral, Gambar bermakna seribu kata dan membantu dalam menggunakan imajinasi. Sebuah gambar sentral akan lebih menarik, terfokus, membantu konsentrasi, dan mengaktifkan otak.

c. Penggunaan warna, bagi otak warna sama menariknya dengan gambar. Warna membuat mind map lebih hidup, menambah energi kepada pemikiran kreatif, dan menyenangkan.

d. Hubungkan cabang-cabang utama kegambar pusat ke tingkat satu dan dua, dan seterusnya, otak akan bekerja menurut asosiasi.

e. Buatlah garis hubung yang melengkung, bukan garis lurus agar tidak membosankan otak.

f. Gunakan satu kata kunci pada setiap garis untuk memberi lebih banyak daya dan fleksibilitas kepada mind map.

g. Gunakan gambar, sebagai pengganti ungkapan kata yang akan disampaikan. Mind map merupakan sebuah jalan pintas yang bisa membantu siapa saja untuk mempersingkat waktu sampai setengahnya untuk menyelesaikan tugas dan bisa dilakukan dalam aktivitas apapun dan saat belajar mata pelajaran apa saja 
(Buran \& Filyukov, 2015; Crowe \& Sheppard, 2012). Jadi jika anak dibiasakan menggunakan mind map, kapasitas otak akan bertambah, dan anak akan terbiasa menghasilkan ide-ide, disamping terlatih memecahkan masalah atau mencari solusi dari cara berpikir yang simultan dan kreatif (Crowe \& Sheppard, 2012). Peta pikiran membantu anak membuat catatan pelajaran lebih menarik, mudah diingat dan dimengerti (Buran \& Filyukov, 2015). Manfaat mind map adalah: Menumbuhkan rasa percaya diri anak, (2) Kreativitas, (3) Berpikir, (4) Rasa ingin tahu, 5) Melatih konsentrasi. Teknik mind map adalah salah satu teknik yang dikembangkan dalam membantu anak belajar memaksimalkan kerja otak kiri dan kanan secara seimbang dengan menggunakan gambar dan warna, melalui cara menuliskan kata kunci yang diberi banyak anak cabang sebagai penjelas dan perluasan dari inti/permasalahan, dengan harapan materi/bacaan yang di mind map kan akan mudah dimengerti dan dipahami anak maupun orang lain yang membacanya.

\section{METODE}

Penelitian dilakukan pada semester genap yaitu bulan April hingga Juni 2011. Obyek penelitian adalah siswa kelas X program keahlian Tata Kecantikan Rambut SMK Negeri 3 Bogor, berjumlah 16 orang siswa, berusia antara 15 - 16 tahun, berjenis kelamin perempuan (15 orang dan satu orang laki-laki, dengan latar belakang sosial ekonomi dan pendidikan orang tua yang beragam. Penelitian ini dilaksanakan dalam minimal dua siklus, dan maksimal tiga siklus, untuk melihat peningkatan hasil belajar dan aktifitas siswa dalam mengikuti mata pelajaran produktif melalui membuat peta pikiran pada saat belajar teori kompetensi pratata dan penataan. Sebelumnya dibuat berbagai input instrumental yaitu Rancangan Pelaksanaan Pembelajaran (RPP) yang akan dijadikan materi PTK yaitu Standar Kompetensi (SK): Melakukan Pratata, dengan Kompetensi Dasar (KD) sebagai berikut; (1), Menjelaskan teknik pratata rambut sesuai dengan alat yang digunakan (2) Melakukan pratata sesuai dengan desain penataan yang akan dibuat dan Kompetensi Melakukan Penataan Rambut dengan Kompetensi dasar (1) Menjelaskan desain penataan rambut (styling), (2) Mengidentifikasi peralatan penataan rambut (styling) dan (3) Melakukan penataan rambut (styling) sesuai karakter. Selain itu pula dibuat perangkat pembelajaran yang berupa: (1) Modul Pratata dan Penataan, (2) Lembar Kerja Siswa, (3) Lembar Pengamatan hasil kerja siswa (peta Pikiran) dan (4) Lembar Evaluasi, dan angket. Sumber data penelitian antara lain siswa, guru, teman sejawat dan kolaborator. Pengumpulan data dilakukan dengan cara:

1. Penelahaan data nilai harian, Pekerjaan Rumah (PR), yaitu membuat peta pikiran tentang materi yang telah di ajarkan, dan performence siswa pada saat di kelas,

2. Melakukan wawancara dengan guru dan siswa sebelum dan setelah pembelajaran berlangsung, untuk mengetahui efektivitas pembelajaran dengan menggunakan pedoman wawancara, kemudian hasil wawancara ditulis, dirangkum dan direduksi.

3. Melakukan pengamatan, selama proses belajar mengajar untuk menggambarkan aktifitas siswa dalam proses pembelajaran

4. Melakukan Tes, untuk mengukur kemampuan siswa. 
5. Menyebarkan angket, untuk mengetahui motivasi siswa dalam pembelajaran.

Berdasarkan pengkajian data hasil belajar siswa pada semester ganjil Tahun Pelajaran 2010-2011, nilai-nilai harian, PR, dan ulangan formatif, tim kolaborator menetapkan kriteria keberhasilan sebagai berikut:

1. Tingginya motivasi dan prestasi belajar siswa, ditunjukkan dengan sikap positif siswa dalam belajar, seperti: antusias, gembira, mau bertanya, berani menjawab, turut serta secara aktif dalam pembelajaran, bertanggung jawab terhadap tugas-tugas baik individual maupun kelompok. Selain itu dilihat dari nilai yang diperoleh, yakni secara klasikal 80\% rata-rata nilai siswa telah mencapai KKM di atas 75 dan individu nilai siswa mencapai KKM di atas 75

2. Instrumen Penelitian, dilihat dari prestasi belajar siswa

Data penelitian dianalisis secara deskriptif dengan menggunakan teknik persentase untuk melihat kecenderungan yang terjadi dalam kegiatan pembelajaran. Faktor yang diteliti adalah:

1. Motivasi Belajar, difokuskan pada dorongan yang menyebabkan siswa belajar dan usaha yang dilakukan untuk mencapai tujuan.

2. Prestasi Belajar, yaitu kemampuan siswa menguasai butir-butir indikator pembelajaran.

Antusiasme siswa dalam Proses Belajar Mengajar, yaitu sikap yang ditunjukkan siswa pada saat pembelajaran, dilihat dari keaktifan siswa di kelas, ketekunan dalam menghadapi tugas, keuletan dalam menghadapi kesulitan, dan minat terhadap pembelajaran.

\section{HASIL}

Untuk mengetahui peningkatan pemahaman siswa peneliti menggunakan tes awal dan akhir belajar. Data tes awal dan tes akhir dan N-Gain kelas eksperimen dan kelas kontrol di analisis, dari hasil analisis data tersebut dapat diketahui sejauh mana peningkatan pemahaman konsep belajar siswa sebelum dan sesudah pembelajaran. Untuk menggetahui keberhasilan peningkatan pemahaman siswa dapat dilihat dari nilai KKM (Kriteria Ketuntasan Minimum). Siswa dikatakan berhasil jika nilai $\geq 75$ dan apabila siswa dikatakan gagal maka nilai yang diperoleh $\leq 75$. Sebanyak 17 siswa laki - laki dan 18 siswa perempuan yang mengikuti masing - masing tes. Hasil pengamatan tampak dalam grafik berikut ini. Dari grafik tersebut dapat dilihat bahwa masih banyak siswa yang pemahaman konsepnya masih tergolong rendah dan belum mencapai nilai KKM yang sebagaimana yang sudah di tentukan guru sebelumnya. Untuk meningkatkan belajar siswa guru harus memberi suatu proses pembelajaran terlebih dahulu sebelum dilakukan tes selanjutnya agar guru bisa mengetahui sejauh mana pemahaman siswa terhadap pembelajaran selama dilakukan di dalam kelas. 


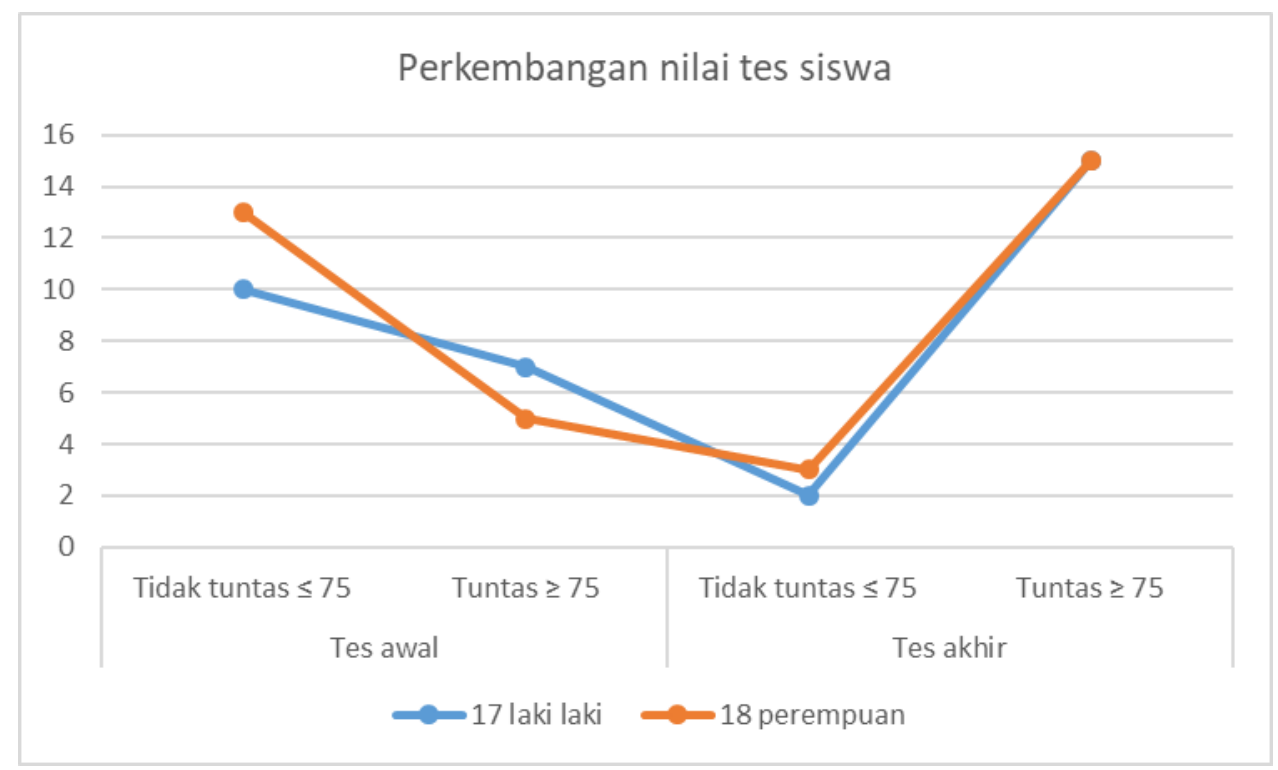

Grafik 1 Perkembangan nilai tes siswa

\section{PEMBAHASAN}

Hasil analis menunjukkan bahwa terdapat peningkatan kemampuan pemahaman konsep belajar siswa dikelas eksperimen dibandingkan dikelas kontrol yang mendapatkan pembelajaran secara konvensional. Artinya pemahaman konsep kelas eksperimen lebih baik dibandingkan dengan kelas kontrol, perbandingan ini dapat dilihat dari perolehan nilai rata-rata tes akhir dan N-Gain dari kedua kelas tersebut dikarenakan dalam kelas eksperimen dapat memberikan kesempatan pada siswa untuk belajar memecahkan masalah baik secara individual mapun kelompok, PBL juga merupakan suatu model yang bisa melatih siswa untuk belajar bagaimana bekerja secara kelompok untuk mencari solusi dari permasalahan di dunia nyata.

Hasil penelitian diuraikan dalam tahapan yang berupa siklus pembelajaran yang dilakukan dalam proses belajar mengajar di kelas. Dalam penelitian ini pembelajaran dilakukan dalam dua siklus sebagaimana pemaparan berikut ini.

A. Siklus Pertama

Siklus pertama terdiri dari empat tahap, yakni perencanaan, pelaksanaan, observasi dan refleksi serta replanning, seperti berikut ini.

\section{Perencanaan (Planning)}

Tim peneliti menyiapkan bahan pembelajaran yang terdiri dari RPP Pratata dengan kompetensi dasar: Menjelaskan teknik pratata rambut sesuai dengan alat yang digunakan, menyiapkan modul Pratata, lembar kerja siswa, contoh peta pikiran, teknik-teknik membuat peta pikiran, lembar pengamatan, lembar soal, lembar wawancara.

2. Pelaksanaan (Acting)

Pada siklus pertama membahas tentang Dasar Kompetensi; Menjelaskan teknik pratata rambut sesuai dengan alat yang digunakan. Di awal pembelajaran guru menyampaikan kepada siswa bahwa dalam pertemuan tersebut guru akan menerapkan metode pembelajaran aktif, yaitu dengan membuat peta pikiran tentang pengetahuan Pratata. Sebelumnya guru sudah mengajarkan bagaimana cara membuat peta pikiran. Pada siklus pertama ketika pertemuan pertama $(5 \mathrm{x}$ 45 menit), siswa dibagi menjadi empat kelompok, dimana dalam kelompok 
tersebut siswa dapat saling berdiskusi dan mengajarkan cara membuat peta pikiran. kemudian siswa mendapat penjelasan materi Pratata.

\section{Observasi}

Observasi dilakukan oleh tim kolaborator dan juga guru model secara bergantian, yaitu mengamati pelaksanaan PBM dengan membuat peta pikiran, menggunakan format observasi yang telah disusun sebelumnya. Tingkat keaktifan siswa di kelas mencapai nilai tertinggi 100 dan nilai terendah 50. Ratarata kelas nilai keaktifan adalah 78 . Hal ini menunjukkan, bahwa sebagian besar siswa aktif di kelas serta menunjukkan motivasi belajar yang tinggi. Disamping pengamatan melalui keaftifan siswa, guru juga meminta siswa untuk menuliskan tentang pendapat mereka dengan metoda menagajar dengan pembuatan peta pikiran dan sejauh mana mereka menguasai materi yang telah dipelajari pada selembar kertas.

Setelah dikumpulkan dan dibaca guru, dapat disimpulkan bahwa hanya sebagian siswa merasa senang dengan metode mengajar hari itu serta mereka dapat menguasai materi dengan lebih cepat namun sebagian siswa masih merasa belum begitu mengerti. Hasil tanya jawab guru dan siswa secara lisan pada saat post tes, juga menunjukan bahwa rata-rata siswa mampu menjawab pertanyaanpertanyaan yang disampaikan oleh guru walaupun masih harus dibantu dengan melihat catatan sesekali.

Bentuk peta pikiran yang dibuat oleh siswa mengenai pratata, menurut penilain peneliti belum begitu bagus, dalam arti, siswa belum menunjukkan kreasi yang maksimal, mungkin dikarenakan belum banyaknya pensil warna yang digunakan, ataupun belum terlalu memahami bagaimana membuat catatan dalam bentuk peta pikiran.

4. Refleksi dan Perencanaan Ulang (Reflecting and Replanning)

Setelah tahap observasi, guru berserta tim kolaborator berkumpul dan melakukan analisis terhadap pelaksanaan siklus pertama, dengan melihat kelebihan dan kekurangannya. Adapun keberhasilan dan kegagalan pada siklus pertama ini adalah sebagai berikut.

a. Keberhasilan dari siklus pertama ini adalah secara umum siswa menunjukkan gairah yang tinggi untuk mengikuti pelajaran dengan metode pembuatan peta pikiran, (hasil obeservasi menunjukan $81.25 \%$ memperoleh nilai keaktifan di atas 75 .

b. Sebagian besar siswa dapat menjawab pertanyaan yang diberikan guru secara lisan.

c. Kekurangannya, hasil peta pikiran belum begitu menarik dan kreatif, hanya sedikit siswa yang hasilnya lumayan bagus.

d. Masih ada siswa yang memperoleh hasil pengamatan dibawah nilai 60, (tiga orang siswa memperoleh skor 58 atau sekitar $18 \%$ siswa ), mereka dinilai masih kurang aktif di kelas.

Untuk memperbaiki kelemahan dan mempertahankan keberhasilan yang telah dicapai pada siklus pertama, maka pada pelaksanaan siklus kedua dibuat perencanaan sebagai berikut.

a. Guru diminta untuk memahami lebih dalam penerapan metode pembelajaran pembuatan peta pikiran, yaitu salah satunya adalah menyediakan lembar kerja yang sudah ada polanya dan mneyediakan alat tulis berwarna. 
b. Guru meningkatkan usaha dan kemampuan untuk membimbing siswa perindividu agar dapat meningkatkan motivasi belajar mereka sehingga semua siswa merasakan bahwa mereka diperhatikan, sehingga, memperoleh nilai di atas kreteria KKM.

B. Siklus Kedua

Bagian ini terdiri dari empat tahap, yakni perencanaan, pelaksanaan, observasi dan refleksi serta replanning, seperti berikut ini.

1. Perencanaan (Planning)

Pada siklus kedua, Tim peneliti memutuskan untuk menyiapkan bahan pembelajaran tentang pengetahuan kompetensi Melakukan Penataan Rambut (Hair Styling), yang terdiri dari RPP penataan dengan kompetensi dasar: Menjelaskan Desain Penataan Rambut (Hair Styling), menyiapkan modul Penataan, lembar kerja siswa, contoh peta pikiran, teknik-teknik membuat peta pikiran, lembar pengamatan, lembar soal, lembar wawancara.

2. Pelaksanaan (Acting)

Pada siklus kedua membahas tentang Dasar Kompetensi; Menjelaskan Desain Penataan Rambut (Hair Styling). Di awal pembelajaran guru menyampaikan kepada siswa bahwa hasil peta pikiran pada pertemuan sebelumnya masih belum begitu bagus, dan dalam pertemuan tersebut guru juga menjelaskan akan kembali menerapkan metode pembelajaran aktif, yaitu dengan membuat peta pikiran tentang pengetahuan Penataan. Berdasarkan hasil peta pikiran sebelumnya, pada kesempatan ini guru menjelaskan bagaimana cara membuat peta pikiran yang lebih menarik yaitu dengan menggunakan kertas polos kosong dan dengan pensil berwarna sehingga akan tanpak lebih menarik. Guru memberikan contoh kertas kosong dengan gambar ditengah-tengah kertas sebagai awal membuat peta pikiran.

Guru membagi tempat duduk siswa menjadi 4 kelompok untuk memudahkan mengawasi kerjasama antar siswa. Dalama hal ini guru ingin menekankan kerjasama kelompok dan memupuk kebersamaan di atara siswa. Seluruh siswa mendapat penjelasan melalui penayangan slide tentang pengetahuan penataan, kemudian siswa membuat catatan kecil tentang poinpoin penting. Kemudian guru memberikan kesempatan kepada siswa untuk berdiskusi kelompok lalu membuat catatan dengan membuat peta pikiran. Siswa juga dapat membaca melalui lembar informasi yang dibagikan oleh guru. Pada siklus kedua ini guru memberikan perhatian lebih kepada siswa ketika mereka membuat peta pikiran. Dengan menggunakan kertas kosong dan pensil warna yang dibagikan oleh guru, siswa lebih kreatif.

3. Observasi

Pada siklus kedua, observasi dilakukan oleh tim kolaborator dan juga guru model secara bergantian, yaitu mengamati pelaksanaan PBM dan bagaimana keaktifan siswa selama membuat peta pikiran. Observasi dilakukan menggunakan format observasi yang telah disusun sebelumnya. Rata-rata skor siswa adalah 88, hal ini menunjukkan peningkatan keaktifan siswa yang signifikan dari rata-rata scor sebelumnya di siklus I adalah 75 . Dan seluruh siswa memperoleh scor yang meningkat. Siswa yang memperoleh scor 100 ada empat orang siswa, meningkat dua kali lipat dari 
scor siswa pada siklus pertama. Nilai terendah pada siklus kedua adalah 67, sedangkan pada siklus pertama scor terendah adalah 50. Tingkat keaktifan siswa di kelas meningkat secara keseluruhan. Rata-rata kelas nilai keaktifan juga meningkat dari 78 pada siklus pertama menjadi 88 pada siklus kedua.

Hal ini menunjukkan bahwa hampir seluruh siswa aktif di kelas serta menunjukkan motivasi belajar yang sangat tinggi. Dari hasil pembuatan peta pikiran oleh siswa, dapat disimpulkan bahwa hampir seluruh siswa menunjukan antusias yang tinggi terlihat dari hasil peta pikiran yang dibuat. Hampir seluruh siswa membuat peta pikiran dengan penuh warna dan sangat kreatif. Keberhasilan ini juga ditunjukkan dengan hasil tes tertulis siswa yang mecampai rata-rata 85.67, dengan perolehan nilai tertinggi 100 dan nilai terendah adalah 96.25. Dua orang siswa memoeroleh nilai 0 karena mereka belum megikuti tes disebabkan absen pada saat tes berlangsung. Hasil tersebut merupakan hasil yang luar biasa, dimana nilai tes siswa kelas X Kecantikan Rambut tahun ajaran 2010/2011 sebelumnya rata-rata hanya sebatas nilai KKM, yaitu 75.

4. Refleksi dan Perencanaan Ulang (Reflecting and Replanning)

Setelah tahap observasi, guru berserta tim kolaborator berkumpul dan melakukan analisis terhadap pelaksanaan siklus kedua dan memperhatikan kelebihan dan kekurangannya. Pada tahap ini tim kolaborator menuliskan beberapa kelebihan dan kekurangan pelaksanaan siklus kedua sebagai berikut:

a. Keberhasilan dari siklus kedua ini adalah secara umum siswa menunjukkan antusias yang meningkat dalam mengikuti pelajaran dengan metode pembuatan peta pikiran, (hasil obeservasi menunjukan 93\% memperoleh skor keaktifan $\geq 75$. Dari 15 orang siswa ada 14 orang siswa yang memperoleh skor lebih beda sama dengan 75 , hanya satu orang siswa yang memperoleh skor 67.

b. Seratus persen siswa memperoleh nilai tes di atas KKM dengan nilai terendah adalah 88.75, tertinggi 100, adalah merupakan indikator keberhasilan yang sangat signifikan pada siklus kedua ini.

c. Hasil peta pikiran rata-rata mendapatkan komen sangat bagus, hasil ini jauh lebih baik dari hasil peta pikiran pada siklus pertama.

d. Pada siklus kedua ini hampir tidak diketemukan kekurangan, hanya mungkin palaksnaan siklus kedua ini dilaksanakan di luar waktu terjadwal (seharusnya dilakukan sebelum masa test semester 2, namun karena beberapa hal, maka siklus kedua baru dapat terlaksana pada bulan Juni di minggu ketiga.

Dari hasil refleksi tersebut di atas dapat disimpulkan bahwa siklus kedua ini sudah berhasil dan tidak perlu dilakukan siklus ketiga, pelaksanaan penelitian ini dianggap selesai.

\section{KESIMPULAN}

Berdasarkan hasil penelitian disimpulkan bahwa, peta pikiran dapat meningkatkan antusias siswa belajar dan meningkatkan prestasi belajar siswa kelas X Tata Kecantikan Rambut pada kompetensi Melakukan Pratata dan Melakukan Penataan Rambut (Hair Styling). Hal ini terbukti dengan meningkatnya keaktifan siswa di kelas pada siklus I sampai II, yaitu dari rata-rata 78 menjadi 88 , dan nilai 
hasil Tes teori pada siklus II mencampai nilai jauh di atas KKM yaitu mencapai nilai rata-rata 85,67 di atas nilai KKM yaitu 75 .

Reduksi hasil wawancara dengan siswa, diambil kesimpulan bahwa ratarata siswa senang dengan metoda mengajar dengan membuat peta pikiran. Menurut mereka dengan metoda pembelajarn aktif ini lebih mengasyikkan, karena dengan membuat peta pikiran mereka lebih dapat memahami pelajaran yang telah dipelajari dan dapat menjawab soal-soal dari tes yang diberikan. Dari hasil observasi pada setiap siklus menunjukkan bahwa motivasi siswa untuk belajar menunjukan peningkatan, terbukti dari hasil pengamatan keaktifan siswa yang menunjukan peningkatan yang sangat berarti dari siklus I mencapai nilai rata-rata 78, dan 88 pada siklus II. Secara individu juga siswa mengalami kemajuan yang sangat berarti, bahwa dari siklus I masing-masing siswa meningkat pada siklus II. Di sini menunjukkan bahwa siswa senang dengan metoda pengajaran yang melibatkan kreatifitas siswa dalam membuat catatan..

\section{SARAN}

Melihat manfaat positif yang didapatkan dari Implementasi Peta Pikiran (Mind Mapping) dalam menguasai Teori kejuruan untuk Meningkatkan Hasil Belajar Siswa Pada Mata Pelajaran Produktif, maka penulis menyarankan agar metoda mengajar seperti ini dapat dilakukan di setiap kelas, setiap kali siswa harus memahami sesuatu teori untuk mendukung suatu kompetensi. Demi kemajuan dunia pendidikan, sebaiknya setiap guru melakukan penelitian tindakan kelas, mengingat bahwa setiap kelas, setiap sekolah dan setiap jenjang pendidikan mempunyai karakteristik berbeda. Masing-masing kelompok siswa memerlukan perlakuan yang sesuai dengan kondisi masing-masing kelompok siswa tersebut.

\section{DAFTAR RUJUKAN}

Bany, Z. U., Sunnati, \& Darman, W. (2014). Perbandingan Efektifitas Penyuluhan Metode Ceramah dan Demonstrasi Terhadap Pengetahuan Kesehatan Gigi dan Mulut Siswa SD. Cakradonya Dental Journal.

Buran, A., \& Filyukov, A. (2015). Mind Mapping Technique in Language Learning. Procedia - Social and Behavioral Sciences. https://doi.org/10.1016/j.sbspro.2015.10.010

Crowe, M., \& Sheppard, L. (2012). Mind mapping research methods. Quality and Quantity. https://doi.org/10.1007/s11135-011-9463-8

D’Antoni, A. V., Zipp, G. P., Olson, V. G., \& Cahill, T. F. (2010). Does the mind map learning strategy facilitate information retrieval and critical thinking in medical students? BMC Medical Education. https://doi.org/10.1186/14726920-10-61

Deliany, N., Hidayat, A., \& Nurhayati, Y. (2019). Penerapan Multimedia Interaktif untuk Meningkatkan Pemahaman Konsep IPA Peserta Didik di Sekolah Dasar. Educare. https://doi.org/10.36555/educare.v17i2.247

Edwards, S., \& Cooper, N. (2010). Mind mapping as a teaching resource. Clinical Teacher. https://doi.org/10.1111/j.1743-498X.2010.00395.x

Fakhriyanur. (2016). Pengembangan Media Pembelajaran Interaktif teknik Animasi 2 Dimensi Berbasis Adobe Flash Untuk Siswa kelas XI Multimedia Di SMK Muhammadiyah 1 Yogyakarta. In Jurnal Pendidikan Teknik Elektronika.

Febiharsa, D., \& Djuniadi, D. (2018). Pengembangan Media Pembelajaran 
Interaktif 3 Dimensi untuk Pembelajaran Materi Pengenalan Lingkungan Pada Anak Usia Dini di Indonesia. Journal of Studies in Early Childhood Education (J-SECE). https://doi.org/10.31331/sece.v1i1.590

Hajar, Y. ., \& Sari, V. T. A. (2018). Analisis kemampuan pemecahan masalah siswa smk ditinjau dari disposisi matematis. Inspiramatika.

Hastuti, A., \& Budianti, Y. (2014). Pengaruh Penggunaan Media Audio Visual Terhadap Hasil Belajar Siswa Pada Mata Pelajaran Ipa Kelas Ii Sdn Bantargebang Ii Kota Bekasi. Pedagogik.

Hayati, N., \& Harianto, F. (2017). Hubungan Penggunaan Media Pembelajaran Audio Visual dengan Minat Peserta Didik pada Pembelajaran Pendidikan Agama Islam di SMAN 1 Bangkinang Kota. Al-Hikmah: Jurnal Agama Dan Ilmu Pengetahuan. hikmah:jaip.2017.vol14(2).1027

Hsiung, C. M. (2012). The effectiveness of cooperative learning. Journal of Engineering Education. https://doi.org/10.1002/j.2168-9830.2012.tb00044.x

Johnson, D. W., Johnson, R. T., \& Smith, K. A. (2014). Cooperative Learning: Improving University Instruction by Basing Practice on Validated Theory. Journal of Excellence in College Teaching. https://doi.org/10.1080/19397030902947041

L.E., E. P. (2018). COOPERATIVE LEARNING DENGAN MODEL TGT (TEAMS GAMES TOURNAMENT) MATERI BILANGAN BULAT BAGI SISWA KELAS IV SEKOLAH DASAR. Buana Matematika : Jurnal Ilmiah Matematika Dan Pendidikan Matematika. https://doi.org/10.36456/buana_matematika.7.2:.1048.85-88

Purnomo, K. I., Murti, B., Suriyasa, P., Program, 1, Magister, S., Keluarga, K., \& Uns, P. (2013). Perbandingan Pengaruh Metode Pendidikan Sebaya Dan Metode Ceramah Terhadap Pengetahuan Dan Sikap Pengendalian Hiv/Aids Pada Mahasiswa Fakultas Olahraga Dan Kesehatan Universitas Pendidikan Ganesha. Jurnal Magister Kedokteran Keluarga.

Slavin, R. E. (2010). Cooperative learning. In International Encyclopedia of Education. https://doi.org/10.1016/B978-0-08-044894-7.00494-2

Sobah Ch., S. N., Suherman, A., \& Wiharna, O. (2018). Penerapan Metode Pembelajaran Drill untuk Mengatasi Kesulitan Belajar Siswa pada Mata Pelajaran Gambar Teknik. Journal of Mechanical Engineering Education. https://doi.org/10.17509/jmee.v4i2.9640

Sudarsana, I. K., Nakayanti, A. R., Sapta, A., Haimah, Satria, E., Saddhono, K., ... Mursalin, M. (2019). Technology Application in Education and Learning Process. Journal of Physics: Conference Series. https://doi.org/10.1088/17426596/1363/1/012061

Susanto, A. (2017). Pemanfaatan ICT (Informations and Communication Technologies) dalam Pembelajaran Anak Usia Dini. Tarbawy: Jurnal Pendidikan Islam. https://doi.org/10.32923/tarbawy.v4i2.820

Ulfa, S. (2016). Pemanfaatan teknologi bergerak sebagai media pembelajaran bagi anak usia dini. Edcomtech. 